\title{
Cana-de-açúcar ensilada com ou sem aditivos químicos: fermentação e composição química ${ }^{1}$
}

\section{Rafael Camargo do Amaral ${ }^{2}$, Alexandre Vaz Pires $^{3}$, Ivanete Susin ${ }^{3}$, Luiz Gustavo Nussio ${ }^{3}$, Clayton Quirino Mendes ${ }^{2}$, Adilson Luis Gastaldello Junior ${ }^{2}$}

\author{
1 Projeto financiado pela FAPESP. \\ 2 Pós-graduação em Ciência Animal e Pastagens - USP/ESALQ. Bolsista FAPESP. \\ ${ }^{3}$ Departamento de Zootecnia - USP/ESALQ - Piracicaba, SP.
}

\begin{abstract}
RESUMO - Objetivou-se com este estudo avaliar os efeitos de aditivos químicos na ensilagem de cana-de-açúcar sobre a dinâmica fermentativa e a composição química das silagens. O experimento foi desenvolvido em delineamento inteiramente casualizado, com cinco repetições. A cana-de-açúcar foi ensilada sem aditivo ou tratada com $1 \%$ (massa verde) de cal virgem ou calcário, constituindo três tratamentos. A dinâmica fermentativa foi analisada com base nas perdas gasosas, nos ácidos orgânicos, na produção de etanol e na composição química das silagens. As menores perdas gasosas foram observadas nas silagens com cal virgem ou calcário. As silagens tratadas com esses aditivos apresentaram maior teor de carboidratos solúveis residuais e de ácidos acético e butírico, além de reduzida fermentação alcoólica. As silagens com os aditivos químicos apresentaram, no momento da abertura, maior teor de cinzas e menor concentração de componentes fibrosos. O teor de proteína observado nas silagens está de acordo com a amplitude preconizada para a forragem in natura. A adição de cal virgem ou calcário no momento da ensilagem melhorou o padrão fermentativo das silagens, promovendo redução das perdas gasosas, inibição da fermentação alcoólica e maior quantidade de carboidratos solúveis remanescentes.
\end{abstract}

Palavras-chave: ácidos orgânicos, calcário, cal virgem, etanol, perdas gasosas

\section{Sugarcane ensiled without or with chemical additives: fermentation and chemical composition}

\begin{abstract}
The objective of this study was to evaluate the effects of chemical additives on the fermentative dynamics and chemical composition of sugarcane silages. The experiment was conducted in a randomized complete design with five replications. Sugarcane was ensiled without additives or with calcium oxide and limestone (1\% as-fed basis) constituing three treatments. The fermentative dynamic was analyzed based on gas losses, organic acids and ethanol production and, silages chemical composition. The calcium oxide and limestone treatments showed the lowest values of gas losses. Silages treated with these two additives also showed higher concentrations of water soluble carbohydrates, acetic and butyric acids, and low alcoholic fermentation. The treatments containing chemical additives presented the highest ash and the lowest fiber concentration. Crude protein for all treatments was in agreement with the values of fresh sugarcane. Calcium oxide or limestone addition at ensiling resulted in a better fermentative pattern, promoting reduction in gas losses, alcoholic fermentation inhibition, and high amounts of residual soluble carbohydrates.
\end{abstract}

Key Words: calcium oxide, ethanol, gas losses, limestone, organic acids

\section{Introdução}

A ensilagem da cana-de-açúcar tem sido um tema amplamente estudado nos últimos anos com a finalidade de reduzir a fermentação alcoólica e a perda no valor nutritivo durante o processo fermentativo, uma vez que a elevada concentração de carboidratos solúveis e a presença de leveduras epifíticas são os principais agravantes na conservação desta forrageira. Segundo Rooke \& Hatfield (2003), a rota metabólica predominante das leveduras é a piruvato descarboxilase acetaldeído e a redução do acetaldeído a etanol. De acordo com McDonald et al. (1991), a produção deste álcool representa perda de aproximadamente $49 \%$ de matéria seca e $0,2 \%$ de energia. Apesar de potencialmente aproveitável como substrato energético para ruminantes, por meio da conversão a acetato no rúmen 
(Chalupa et al., 1964), há perda do etanol produzido durante a estocagem (Alli et al., 1982) e descarregamento do silo.

Diversos aditivos têm sido utilizados na ensilagem da cana-de-açúcar, com resultados bastantes variáveis (Freitas et al., 2006). Recentemente, a utilização de aditivos químicos, principalmente os alcalinizantes de meio, tem se destacado no processo de conservação da cana-de-açúcar. Esses aditivos interferem na dinâmica fermentativa, alterando o $\mathrm{pH}$ e a pressão osmótica da massa de forragem $\mathrm{e}$, por conseguinte, inibindo o desenvolvimento de microrganismos indesejáveis durante a fermentação do material ensilado (Santos, 2007).

Castrillón et al. (1978) verificaram que a utilização do hidróxido de sódio na ensilagem da cana-de-açúcar permitiu a alteração do processo fermentativo, reduzindo a fermentação alcoólica e aumentando a concentração de ácido lático e a digestibilidade. Segundo Balieiro Neto et al. (2007) a adição de cal virgem nas silagens de cana-deaçúcar promove solubilização parcial da hemicelulose, de modo que a adição de $2 \%$ do aditivo acarreta aumento da digestibilidade verdadeira in vitro, redução dos constituintes da parede celular e manutenção da FDN e hemicelulose após a abertura dos silos. Cavali et al. (2006), avaliando diferentes doses de cal virgem em silagens de cana-de-açúcar, observaram menores concentrações nos valores de FDN, FDA e hemicelulose e maiores coeficientes de digestibilidade nas silagens tratadas.

Objetivou-se com este trabalho avaliar os efeitos dos aditivos químicos cal virgem ou calcário sobre a dinâmica fermentativa e a composição química da cana-de-açúcar ensilada.

\section{Material e Métodos}

O experimento foi realizado nas instalações do SIPOC (Sistema Intensivo de Produção de Ovinos e Caprinos) do Departamento de Zootecnia da Escola Superior de Agricultura "Luiz de Queiroz" (USP/ESALQ). O corte e a ensilagem da cana-de-açúcar foram realizados em 20 de setembro de 2005, após aproximadamente 12 meses de crescimento vegetativo. $\mathrm{O}$ valor do grau Brix da forrageira foi determinado utilizando-se refratômetro de campo (marca TOKYO ${ }^{\circledR}$ modelo 032), que indicou valor médio de $23^{\circ}$. A variedade industrial utilizada foi a RB85-5453, colhida mecanicamente com colhedora de forragem marca Mentamint ${ }^{\mathbb{R}}$, tracionada por trator, regulada para corte com tamanho médio de partículas entre 5 a $10 \mathrm{~mm}$.

Foram confeccionadas três silagens: controle $=$ canade-açúcar sem aditivo; cal virgem $1 \%$ = cana-de-açúcar tratada com $1 \%$ de cal virgem; calcário = cana-de-açúcar tratada com $1 \%$ de calcário calcítico. Os aditivos foram aplicados na forma pulverulenta após a picagem e pesagem da forragem, utilizando-se um vagão forrageiro. A quantidade de cada aditivo foi calculada em relação à matéria natural da forragem. Após a mistura da cana-de-açúcar com o respectivo aditivo, o vagão forrageiro foi acionado durante 10 minutos para homogeneização e posteriormente a forragem foi acondicionada nos silos experimentais.

Foram utilizados como silos experimentais 15 tambores de plástico previamente pesados, cada um com capacidade de 200 litros, revestidos internamente com saco plástico, com tampas adaptadas com válvulas do tipo "Bunsen", confeccionadas com mangueira de látex com uma perfuração ao centro para permitir a saída de gases e impossibilitar a entrada de ar. A forragem foi compactada por pisoteio humano, tomando-se como critério camadas de aproximadamente 5 a $10 \mathrm{~cm}$ de espessura. Após a acomodação final do material, o saco plástico foi amarrado e o tambor fechado para evitar a entrada de ar. Em seguida os tambores foram pesados para mensuração dos valores de densidade $\left(\mathrm{kg} \mathrm{MS} / \mathrm{m}^{3}\right)$ e determinações posteriores de perdas gasosas, armazenados em local protegido e mantidos em temperatura ambiente. Decorridos 365 dias de armazenamento, os silos foram pesados, abertos e amostrados ao longo de seu perfil com auxílio de cavadeira manual. Após a retirada da silagem, o conteúdo foi homogeneizado e amostras de aproximadamente $2 \mathrm{~kg}$ foram congeladas para posteriores análises.

As perdas por produção de gases foram calculadas pela subtração do peso entre a quantidade de matéria seca inicial e final acondicionada nos tambores, descontando-se o peso do tambor vazio em ambos os casos, expressas em porcentagem, em relação à quantidade de matéria seca inicialmente ensilada.

A avaliação do tamanho de partículas das silagens foi realizada com base na estratificação das partículas por meio do método "Penn State Particle Size" (Lammers et al., 1996). Entretanto, foi incorporada uma adaptação ao método original realizada por Mari \& Nussio (2002) com a inserção de uma peneira adicional com orifícios de diâmetro de $38 \mathrm{~mm}$. Dessa forma, obteve-se o material retido com diâmetro superior a $38 \mathrm{~mm}$, entre 38 e $19 \mathrm{~mm}$, entre 19 e $7,80 \mathrm{~mm}$ e inferior a $7,80 \mathrm{~mm}$. O tamanho médio de partículas foi estimado por meio da ponderação da proporção de retenção do material em cada uma das peneiras.

As análises bromatológicas foram realizadas no Laboratório de Bromatologia do Departamento de Zootecnia da ESALQ/USP. As amostras de cana-de-açúcar colhidas no momento da ensilagem e após a abertura dos silos foram secas em estufa a $60^{\circ} \mathrm{C}$ por 72 horas de acordo com 
Silva \& Queiroz (2002) e posteriormente moídas em moinho tipo Wiley provido de peneira com perfurações de $1 \mathrm{~mm}$.

As concentrações de matéria seca (MS) e cinzas (MM) foram determinadas conforme a AOAC (1990). O teor de proteína bruta $(\mathrm{PB})$ foi obtido pela combustão das amostras em equipamento autoanalisador de nitrogênio, da marca LECO $^{\circledR}$ (modelo FP-528), segundo Wiles et al. (1998). Os teores de fibra insolúvel em detergente neutro (FDN) foram obtidos pelo método sequencial proposto pela ANKOM $^{\circledR}$ Fiber Analyser (ANKOM Technology Corporation, Fairport, NY) e descrito por Holden (1999), utilizando para esta determinação amilase e sulfito de sódio. Os teores de fibra insolúvel em detergente ácido (FDA) e lignina foram calculados segundo método de Van Soest (1994). A fração hemicelulose foi calculada pela diferença observada entre os teores de FDN e FDA. A fração celulose foi calculada pela diferença entre os teores de FDA e lignina.

O extrato aquoso das amostras de cana-de-açúcar no momento da ensilagem e do material ensilado foi preparado segundo metodologia proposta por Kung Jr. (1996), em que, uma alíquota de $25 \mathrm{~g}$ de forragem úmida e $225 \mathrm{~mL}$ de água deionizada foram adicionadas e processadas durante um minuto em liquidificador industrial, modelo TA-02, da marca Skymsen ${ }^{\circledR}$. Em seguida, a solução foi filtrada em papel-filtro Whatman ${ }^{\circledR} 54$, acidificada com ácido sulfúrico $50 \%$ e centrifugada durante 15 minutos a $10.000 \mathrm{rpm}$. Mediu-se o pH após o preparo do extrato, antes da filtragem, por meio de potenciômetro digital modelo DM 20, marca Digimed $^{\circledR}$.

O extrato obtido foi utilizado para análises de carboidratos solúveis (CHO sol.), etanol e ácidos graxos voláteis (AGV). A concentração de carboidratos solúveis foi obtida pelo método colorimétrico, adaptando-se a metodologia descrita por Dubois et al. (1956) com leitura em comprimento de onda de $490 \mathrm{~nm}$. A adaptação foi realiza em relação ao aumento na diluição das amostras, uma vez que a cana-de-açúcar in natura ou ensilada apresenta teores elevados de carboidratos solúveis.

$\mathrm{O}$ teor de etanol foi determinado diretamente por meio de leitura em autoanalisador YSI 2700 Select $^{\mathbb{R}}$ (Biochemistry Analyser, Yellow Spring, OH, EUA) calibrado com soluções padronizadas de etanol $(2 \mathrm{~g} / \mathrm{L})$. Após leitura, o equipamento forneceu o valor da concentração de etanol, em $\mathrm{g} / \mathrm{L}$.

Para análise dos ácidos graxos voláteis (ácido acético e ácido butírico), $800 \mu \mathrm{L}$ do extrato aquoso da silagem, juntamente com $200 \mu \mathrm{L}$ de ácido fórmico e $100 \mu \mathrm{L}$ de padrão interno foram transferidos para um frasco de vidro. A leitura foi realizada em cromatógrafo líquido gasoso, CLG (Hewlett Packard ${ }^{\circledR}$ 5890, series II).
O delineamento experimental utilizado foi o inteiramente casualizado com cinco repetições. Os dados foram analisados por meio do procedimento GLM do programa estatístico SAS ${ }^{\circledR}$, versão 8 para Windows ${ }^{\circledR}$ (SAS, 1999). O teste Tukey com nível de significância de 5\% foi utilizado para efeito de comparação de média entre tratamentos.

\section{Resultados e Discussão}

Os teores de MS, FDN, hemicelulose e FDA da cana-deaçúcar no momento da ensilagem estão dentro da amplitude de valores relatados pela literatura (Tabela 1). De maneira similar, os teores de PB estão de acordo com os encontrados por Schmidt et al. (2007), que observaram valor médio de PB de 3,4\%. Da mesma forma, Santos et al. (2009) avaliaram silagens de cana-de-açúcar tratadas com aditivos e observou valores de MS variando de 32 a $35 \%$, de FDN entre 48 e $52 \%$, de hemicelulose entre 17 e $22 \%$ e de FDA entre 29 e $32 \%$.

O teor de cinzas observado no tratamento controle apresentou valor inferior ao encontrado por Schmidt et al. (2007). Por outro lado, Santos et al. (2009), avaliando silagens de cana-de-açúcar aditivadas com cal virgem e calcário, encontraram valores de cinzas bem menores no momento da ensilagem (2,3\% para a silagem controle e de 4,5 e $3,2 \%$ para as silagens contendo cal virgem ou calcário, respectivamente). Da mesma forma, neste trabalho, verificou-se aumento nos valores de cinzas quando o aditivo químico foi inserido no volumoso, o que possivelmente está relacionado ao fato de os aditivos serem de origem mineral e apresentarem grande proporção desta fração em sua totalidade. Os dados de carboidratos solúveis (Tabela 1) estão próximos aos relatados por Schmidt et al. (2007), que obtiveram teores de aproximadamente $11 \%$ de carboidratos

Tabela 1 - Composição química da cana-de-açúcar in natura e acrescida ou não de aditivos no momento da ensilagem (\% MS)

\begin{tabular}{|c|c|c|c|}
\hline \multirow[b]{2}{*}{ Variável } & \multicolumn{3}{|c|}{ Tratamento } \\
\hline & Controle $^{1}$ & Cal virgem $1 \%$ & Calcário $1 \%$ \\
\hline Matéria seca, \% & 37,3 & 36,7 & 35,6 \\
\hline Cinzas & 5,2 & 9,8 & 6,3 \\
\hline Proteína bruta & 3,5 & 3,3 & 3,2 \\
\hline $\begin{array}{l}\text { Fibra em detergente } \\
\text { neutro }\end{array}$ & 54,1 & 49,9 & 51,4 \\
\hline Hemicelulose & 22,8 & 20,2 & 21,3 \\
\hline $\begin{array}{l}\text { Fibra em detergente } \\
\text { ácido }\end{array}$ & 31,4 & 29,6 & 30,1 \\
\hline Celulose & 26,6 & 24,8 & 24,3 \\
\hline Lignina & 4,8 & 4,9 & 5,8 \\
\hline Carboidratos solúveis & 14,1 & 14,3 & 14,5 \\
\hline $\mathrm{pH}$ & 5,4 & 10,6 & 8,0 \\
\hline
\end{tabular}


solúveis no momento da ensilagem ao avaliarem silagens de cana-de-açúcar tratadas com aditivos químicos e microbianos.

Com a inclusão dos aditivos na cana-de-açúcar, os valores de $\mathrm{pH}$ elevaram em mais de 5 unidades na cana-deaçúcar contendo $1 \%$ de cal virgem e 2 unidades na silagem contendo 1\% de calcário. Esses valores são superiores aos encontrados por Santos et al. (2008), que observaram valores de $\mathrm{pH}$ de 8,7 e 4,7 nas silagens aditivadas com $1 \%$ de cal virgem e $1 \%$ de calcário, respectivamente.

Embora o tamanho médio das partículas não tenha sido influenciado pelos aditivos $(\mathrm{P}>0,05)$ - durante a confecção das silagens, respeitou-se a espessura de camada adicionada ao silo e a homogeneidade dos pesos humanos durante a compactação -, verificou-se diferença entre os aditivos $(\mathrm{P}<0,01)$ nos valores de densidade das silagens. As silagens tratadas com os aditivos químicos apresentaram densidade mais elevada em comparação à cana-de-açúcar ensilada sem aditivo (Tabela 2).

Os valores de densidade encontrados neste trabalho foram inferiores àqueles preconizados por Holmes \& Muck (1999) como mínimos para a compactação ideal $\left(225 \mathrm{~kg} \mathrm{MS} / \mathrm{m}^{3}\right)$. Por outro lado, esses valores são próximos aos descritos por Schmidt (2006), que obteve valores entre 139 e $157 \mathrm{~kg} \mathrm{MS} / \mathrm{m}^{3}$ ao ensilarem cana-de-açúcar em silos tipo poço.

Giger-Reverdin (2000) avaliou alguns parâmetros físicos de ingredientes utilizados em dietas de ruminantes, entre eles, a silagem de milho, e descreveu que os valores de densidades são negativamente correlacionados ao teor de FDN do material. Dessa forma, neste trabalho, provavelmente o tratamento da cana-de-açúcar com a cal virgem ou com o calcário, além de reduzir os teores de FDN em relação à silagem sem aditivo, desestruturou a parede celular da forragem, permitindo melhor acomodação da forragem no silo. Segundo Van Soest (1994), algumas ligações que ocorrem durante a formação da parede celular são susceptíveis à ação de agentes alcalinizantes. Além da ação hidrolítica no complexo lignina, carboidratos e ácidos ferúlico e p-cumárico, os agentes alcalinizantes podem ainda atuar na estrutura dos polissacarídeos. Esses agentes promovem a expansão das moléculas de celulose, causando ruptura das ligações intermoleculares das pontes de hidrogênio. Além disso, atuam solubilizando parte da hemicelulose que estava ligada à celulose por meio de ligações covalentes (Jackson, 1977). Segundo Klopfenstein (1978), o processo permite a expansão e hidratação das fibras.

As silagens com os aditivos químicos apresentaram menor perda gasosa $(\mathrm{P}<0,01)$ e silagem contendo calcário foi a mais eficiente nessa redução (13,5\% a menos) (Tabela 3$)$. A silagem tratada com a cal virgem, apesar de possuir valor intermediário de perdas gasosas, apresentou redução de $8,2 \%$ em relação àquela sem aditivo. Trabalhando com canade-açúcar ensilada com $1 \%$ de cal virgem e $1 \%$ de calcário, Santos et al. (2008), encontraram valores semelhantes de perdas gasosas na silagem contendo cal virgem, porém,

Tabela 2 - Densidade e tamanho médio de partículas (TMP) das silagens de cana-de-açúcar tratadas com aditivos químicos

\begin{tabular}{lccccc}
\hline Variável & \multicolumn{3}{c}{ Tratamento } & EPM $^{2}$ & P $>$ F \\
\cline { 2 - 5 } & Controle $^{1}$ & Cal virgem $1 \%$ & Calcário $1 \%$ & 3,00 & $<0,001$ \\
\hline Densidade, $\mathrm{kg} \mathrm{MS} / \mathrm{m}^{3}$ & $171,2 \mathrm{~b}$ & $195,1 \mathrm{a}$ & $188,2 \mathrm{a}$ & 0,22 & 0,28 \\
TMP, cm & 2,6 & 2,2 & 1,8 & \\
\hline
\end{tabular}

Médias seguidas da mesma letra não diferem entre si $(\mathrm{P}>0,05)$

${ }^{1}$ Controle $=$ silagem de cana-de-açúcar sem aditivo.

$2 \mathrm{EPM}=$ erro-padrão da média

Tabela 3 - Perdas e dinâmica fermentativa das silagens de cana-de-açúcar tratadas com aditivos químicos no momento da abertura dos silos experimentais $(\% \mathrm{MS})$

\begin{tabular}{|c|c|c|c|c|c|}
\hline \multirow[t]{2}{*}{ Variável } & \multicolumn{3}{|c|}{ Tratamento } & \multirow[t]{2}{*}{$\mathrm{EPM}^{2}$} & \multirow[t]{2}{*}{$\mathrm{P}>\mathrm{F}$} \\
\hline & Controle $^{1}$ & Cal virgem $1 \%$ & Calcário $1 \%$ & & \\
\hline Perdas gasosas & $21,4 \mathrm{a}$ & $13,2 b$ & $7,9 \mathrm{c}$ & 1,58 & $<0,001$ \\
\hline $\mathrm{pH}$ & $3,4 \mathrm{c}$ & $4,0 \mathrm{a}$ & $3,6 b$ & 0,07 & $<0,001$ \\
\hline Carboidratos solúveis & $2,9 \mathrm{c}$ & $4,4 \mathrm{~b}$ & $6,0 \mathrm{a}$ & 0,37 & $<0,001$ \\
\hline Etanol & $4,3 \mathrm{a}$ & $1,2 \mathrm{~b}$ & $1,2 \mathrm{~b}$ & 0,42 & $<0,001$ \\
\hline Ácido acético & $1,3 \mathrm{~b}$ & $1,6 \mathrm{a}$ & $1,5 \mathrm{a}$ & 0,40 & 0,005 \\
\hline Ácido butírico & $0,2 b$ & $3,1 \mathrm{a}$ & $0,4 \mathrm{~b}$ & 0,37 & $<0,001$ \\
\hline
\end{tabular}

Médias seguidas da mesma letra não diferem entre si $(\mathrm{P}>0,05)$.

${ }^{1}$ Controle $=$ silagem de cana-de-açúcar sem aditivo

${ }^{2} \mathrm{EPM}=$ erro- padrão da média. 
observou resultados superiores para a silagem controle $(32,1 \%)$ e aquela com a adição de calcário $(17,2 \%)$. Balieiro Neto et al. (2005) avaliaram o efeito de doses de cal virgem na ensilagem da cana-de-açúcar e encontraram perdas gasosas de $9,7 \%$ na silagem tratada com $1 \%$ desse aditivo. Pedroso et al. (2007) também encontraram redução das perdas gasosas e aumento da recuperação de MS quando utilizaram aditivo alcalinizante (hidróxido de sódio) nas doses de 1 a 3\%, o qual apresentou semelhança aos aditivos utilizados neste trabalho, com elevação do $\mathrm{pH}$ da forragem no momento da ensilagem e no padrão de fermentação. Segundo esses autores, durante o processo fermentativo, microrganismos consomem proteína e carboidratos. A fermentação de carboidratos pode gerar vários produtos, como ácidos orgânicos, etanol, água, ATP e dióxido de carbono. A produção de gás carbônico durante a fermentação por leveduras é bastante significativa na ensilagem da cana-de-açúcar e as perdas por gases constituem um parâmetro de muita importância, pois apresentam alta correlação com a produção de etanol por leveduras.

Diante do exposto e considerando os aditivos químicos alcalinizantes, pode-se inferir que o tratamento de silagens de cana-de-açúcar com esses aditivos diminui as perdas inerentes ao processo de conservação. Possivelmente, a ação alcalinizante do aditivo, por meio da elevação dos valores de pH no momento da ensilagem (Tabela 1) e pela capacidade de aumento na pressão osmótica do meio, fez com que o ambiente antes favorável ao desenvolvimento das leveduras se tornasse inapropriado, reduzindo perdas por gases nestas silagens.

As silagens tratadas com os aditivos químicos apresentaram os maiores valores de $\mathrm{pH}(\mathrm{P}<0,01)$ e a silagem contendo $1 \%$ de cal virgem apresentou o maior valor, seguida por aquela tratada com $1 \%$ de calcário e pela silagem controle. Esses valores estão de acordo com os de Santos et al. (2008), que trabalharam com silagens de canade-açúcar tratadas com diversos aditivos e obteve valores de $\mathrm{pH}$ de 3,5; 4,1 e 3,7 para as silagens controle, tratada com $1 \%$ de cal virgem e tratada com $1 \%$ de calcário, respectivamente. Segundo esse autor, os maiores valores de $\mathrm{pH}$ nas silagens tratadas com aditivos alcalinizantes foram ocasionados pelo seu poder tamponante, uma vez que a dissociação dos átomos presentes nos aditivos químicos gera cargas aniônicas capazes de neutralizar os íons hidrogênio oriundos dos ácidos orgânicos produzidos durante a fermentação.

Outro fato a ser destacado é a relação entre os valores de $\mathrm{pH}$ no momento da ensilagem (Tabela 1) com os valores no momento da abertura dos silos. Em decorrência da elevação do poder tamponante das forragens tratadas com os aditivos químicos alcalinizantes (Santos et al., 2008; Siqueira et al., 2007), a quantidade de ácidos orgânicos requerida para a redução do $\mathrm{pH}$ nestas silagens é maior que para as silagens testemunhas. Segundo Santos et al. (2008), o tamponamento dos ácidos produzidos pela fermentação serve de estímulo para maior conversão dos açúcares solúveis em ácido lático, aumentando a concentração desse produto final e evitando a produção de etanol. A análise conjunta dos dados de carboidratos solúveis, etanol, ácido acético e butírico (Tabela 3) comprovam essa linha de raciocínio.

A produção de etanol nas silagens tratadas foi menor que na silagem controle, o que indica que os aditivos controlaram a intensa atividade das leveduras, que possivelmente foram inibidas pelos ácidos fracos produzidos no período de fermentação. Além disso, também foram observados maiores valores de carboidratos solúveis $(\mathrm{P}<0,01)$ para silagens tratadas. A silagem tratada com $1 \%$ de calcário apresentou maior concentração de carboidratos solúveis no momento da abertura dos silos em relação aos demais tratamentos $(\mathrm{P}<0,01)$, seguida da silagem com $1 \%$ de cal virgem e da silagem controle. A silagem tratada com $1 \%$ de cal virgem, apesar da maior redução dos carboidratos solúveis em relação à silagem tratada com calcário, foi superior $(\mathrm{P}<0,01)$ à silagem controle.

Segundo Alli et al. (1983), a intensa atividade de leveduras durante o processo de conservação da cana-deaçúcar converte açúcares a etanol, dióxido de carbono e água, podendo causar reduções de até $70 \%$ na concentração de carboidratos solúveis. Neste trabalho, as reduções foram de 79,3; 69,0 e 58,7\% nas silagens controle e com $1 \%$ de cal virgem e $1 \%$ de calcário, respectivamente. Dessa forma, a silagem controle apresentou padrão fermentativo indesejável em relação às demais, possivelmente em virtude da maior intensidade de atuação das leveduras, as quais, segundo McDonald et al. (1991), não são inibidas em ambientes com valores de $\mathrm{pH}$ variando entre 3,5 e 6,5.

Os teores de etanol (Tabela 3 ) indicaram diferença $(\mathrm{P}<0,01)$ entre os aditivos e foram maiores na silagem controle em comparação àquelas tratadas com os aditivos alcalinizantes, cujo valor médio foi de $1,2 \%$. Esses valores estão de acordo com os dados obtidos por Santos et al. (2008), que avaliaram silagens de cana-de-açúcar tratadas com cal virgem e calcário e observou teores de etanol de 4,8; 0,4 e $1,4 \%$ nas silagens controle, tratada com $1 \%$ de cal virgem e com $1 \%$ de calcário, respectivamente. Segundo McDonald et al. (1991), a produção de etanol representa perdas de aproximadamente $49 \%$ de matéria seca dos substratos e essa perda é composta principalmente de carboidratos solúveis. Os dados obtidos para a silagem 
controle confirmam essa informação, pois nessa silagem verificou-se elevação significativa no teor de etanol $(\mathrm{P}<0,01)$, que resultou na silagem com maior consumo de carboidratos solúveis e maiores perdas gasosas (Tabela 3).

A concentração de ácido acético nas silagens tratadas com os aditivos foi maior que na silagem controle (Tabela 3 ). Esses valores são inferiores aos encontrados por Schmidt et al. (2007), que encontraram para as silagens de cana-deaçúcar tratadas com aditivos químicos e microbianos valores médios de 2,3\%. Da mesma forma, Silva et al. (2003) observaram valores de ácido acético mais altos $(2,8 \%)$ na silagem de cana-de-açúcar sem aditivo. Vieira et al. (2004) verificaram que o tratamento combinado de ureia e carbonato de cálcio elevou de forma significativa o $\mathrm{pH}$ final e as concentrações dos ácidos acético e lático. Segundo esses autores, provavelmente ocorreu somatório de efeito tamponante dos sais de amônio e cálcio.

As concentrações de ácido butírico (Tabela 3 ) diferiram entre as silagens $(\mathrm{P}<0,01)$ e foram maiores na silagem tratada com $1 \%$ de cal virgem. A concentração de ácido butírico obtida na silagem tratada com $1 \%$ de cal virgem foi inesperada, contrariando valores encontrados na literatura para esta variável. Poucos são os trabalhos que citam concentrações de ácidos orgânicos, principalmente o ácido acético e butírico em silagens de cana-de-açúcar. Schmidt et al. (2007) não observaram diferença na concentração de ácido butírico em silagens de cana-de-açúcar tratadas com aditivos e encontraram valores médios de 0,05\% da MS. Bolsen et al. (1983) avaliaram silagens de trigo aditivadas quimicamente e sob diferentes concentrações de MS e determinaram que nas silagens com $27 \%$ de MS houve aumento na concentração de ácido butírico de zero, referente à silagem controle, para $5,9 \%$ e $8,6 \%$ nas silagens tratadas com hidróxido de sódio e hidróxido de cálcio, respectivamente.

McDonald et al. (1991) descreveram que, durante o processo de ensilagem de forragens, inicialmente o grupo de microrganismos que atua na acidificação da massa de forragem é o das enterobactérias, as quais sobrevivem até o momento em que bactérias ácido láticas homofermentativas apresentem condições ideais de desenvolvimento (menores valores de $\mathrm{pH}$ ), iniciando a conversão de açúcares em ácido lático. Assim, com a queda de $\mathrm{pH}$, as enterobactérias são inibidas e prevalecem na massa ensilada as bactérias ácido-láticas.

Dessa forma, pode-se inferir que a elevação dos valores de $\mathrm{pH}$ no momento da ensilagem e o provável aumento do poder tamponante das silagens tratadas, conforme relatado por Santos et al. (2008), foram os principais fatores que determinaram o padrão fermentativo nas silagens. Fatos que propiciaram condições para o desenvolvimento de microrganismos como bactérias heterofermentativas e clostrídeos.

Na silagem contendo $1 \%$ de cal virgem, o maior valor de ácido butírico pode ser explicado pelo maior $\mathrm{pH}$ da silagem, o qual permitiu desenvolvimento de clostrídeos, que, segundo Pahlow et al. (2003), além de converterem açúcares em ácido butírico, também utilizam o ácido lático e o ácido acético para essa conversão. Em silagens de cana-deaçúcar tratadas com aditivos alcalinizantes, observou-se aumento na produção de ácido lático (Santos et al., 2008), fato que possivelmente contribuiu para maior produção desse ácido orgânico.

Além disso, nas silagens de cana-de-açúcar tratadas com cal virgem, a atividade dos clostrídeos possivelmente foi maior em relação à das silagens tratadas com calcário ou sem aditivo. Segundo Rooke \& Hatfield (2003), clostrídeos geram perdas de até $34 \%$ de MS e $22,1 \%$ de energia e as bactérias heterofermentativas provocam $13 \%$ de perdas de MS e $20,4 \%$ de energia. Portanto, de acordo com as perdas gasosas encontradas neste trabalho (Tabela 3), pode-se inferir que, pelo fato da silagem tratada com cal virgem apresentar maior perda gasosa e menor concentração de carboidratos solúveis em relação à tratada com calcário, a atuação de clostrídeos foi maior. Por outro lado, a silagem não tratada com aditivo químico possivelmente não teve participação desse grupo de bactérias durante a fermentação. Assim, a elevada produção de gases e o baixo conteúdo de carboidratos solúveis (Tabela 3 ) podem ser explicados pela atuação de leveduras, as quais propiciaram elevada concentração de etanol nessa silagem.

Os teores de MS diferiram entre as silagens $(\mathrm{P}<0,01)$, de modo que aquela tratada com $1 \%$ de calcário apresentou o maior teor, seguida da silagem tratada com $1 \%$ de cal virgem e da silagem controle (Tabela 4). Esses valores estão de acordo com os reportados por Schmidt et al. (2007), que observaram nas silagens de cana-de-açúcar tratadas com aditivos químicos alcalinizantes e bacterianos valores de MS variando entre 29,7 e 30,9\%. Por outro lado, Pedroso et al. (2007) observaram em silagens de cana-de-açúcar tratadas com aditivos químicos alcalinizantes valores de MS mais variados, entre 23,7 e 29,2\%.

A diferença nos teores de MS observadas neste trabalho(Tabela 4) pode ser explicada pelo perfil fermentativo de cada silagem. A diferença entre os teores de MS no momento da ensilagem e na abertura dos silos foram de 8,$9 ; 6,2$ e 3,5 unidades, respectivamente, para a silagem controle, silagem tratada com $1 \%$ de cal virgem ou tratada com 1\% de calcário (Tabelas 1, 3 e 4). Portanto, a silagem controle apresentou maior diferença, provavelmente em 
Tabela 4 - Valor nutritivo das silagens de cana-de-açúcar tratadas com aditivos químicos no momento da abertura dos silos experimentais (\% MS)

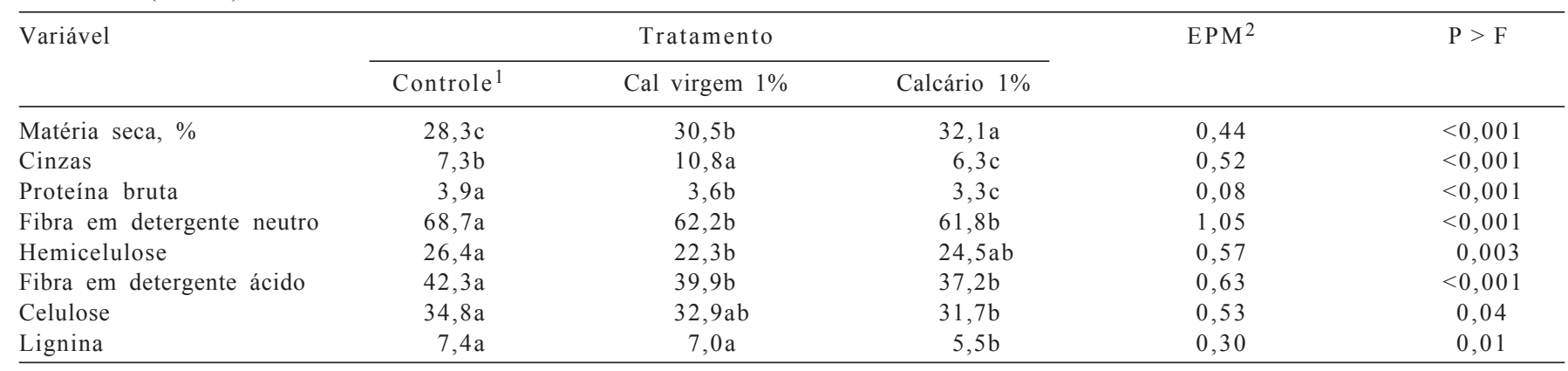

Médias seguidas da mesma letra não diferem entre si $(\mathrm{P}>0,05)$.

${ }^{1}$ Controle $=$ silagem de cana-de-açúcar sem aditivo.

${ }^{2} \mathrm{EPM}=$ erro-padrão da média.

decorrência da maior atividade de leveduras, o que acarretou maiores perdas gasosas e maior consumo de carboidratos solúveis (Tabela 3), corroborando relatos de Rooke \& Hatfield (2003), os quais mencionaram que a intensa atividade das leveduras pode gerar elevada produção de etanol e perdas de MS de até $49 \%$. A silagem tratada com $1 \%$ de calcário possivelmente apresentou melhor padrão de fermentação, pois teve menor variação nos teores de MS, além de menor perda gasosa e maior concentração de carboidratos solúveis no momento da abertura dos silos.

Os valores de cinzas diferiram entre as silagens e foram maiores ( $\mathrm{P}<0,01)$ na silagem tratada com $1 \%$ de cal virgem. Inesperadamente, na silagem tratada com $1 \%$ de calcário, observou-se o menor valor $(\mathrm{P}<0,01)$. O aumento na fração mineral da silagem controle, em relação aos valores da forragem antes da ensilagem, foi possivelmente ocasionado pela excessiva perda de componentes solúveis dessa silagem. Santos et al. (2009) também verificou aumento no teor de cinzas em silagens de cana-de-açúcar tratadas com cal virgem e calcário. Na silagem com $1 \%$ de cal virgem, o autor encontrou valor de $6,1 \%$, ao passo que, na silagem contendo $1 \%$ de calcário, constatou-se valor de $4,7 \%$ de cinzas. Avaliando silagem de cana-de-açúcar tratadas com $1 \%, 2 \%$ e $3 \%$ de $\mathrm{NaOH}$, Pedroso et al. (2007) observaram valores superiores, com elevação na fração mineral, com valores de 9,1,11,0 e 11,2\% da MS, respectivamente.

No momento da abertura dos silos, a concentração de proteína bruta diferiu entre as silagens $(\mathrm{P}<0,01)$ e foi maior na silagem controle, seguida das silagens tratadas com cal virgem e tratadas com calcário. De acordo com os valores encontrados na cana-de-açúcar in natura (Tabela 1), esses aditivos propiciaram aumento dessa fração ao longo do período de conservação. Possivelmente, o desaparecimento de outras frações orgânicas solúveis, as perdas de carbono na forma de gases e o ambiente favorável para a atividade de microrganismos deterioradores favoreceu o aumento da concentração da fração proteica dessas silagens. A utilização de cal virgem ou do calcário resultou em silagens com menores porcentagens de proteína bruta em relação à silagem controle. Entretanto, comparando os teores da cana-de-açúcar in natura (Tabela 1) aos da silagem no momento da abertura (Tabela 4), observou-se pequeno aumento dessa fração entre as silagens $(0,4 ; 0,3$ e $0,1 \%$ para a silagem controle e aditivada com $1 \%$ de cal virgem e calcário, respectivamente). De acordo com dados da literatura, o processo fermentativo da cana-de-açúcar tem pouco efeito na degradação da proteína (Balieiro Neto et al., 2007; Santos et al., 2009), uma vez que houve pequena alteração dessa fração ao longo do tempo e os valores obtidos estão dentro da amplitude preconizada por Faria (1993) para a forragem in natura, variando entre 1,80 e $4,70 \%$ da MS.

Os teores de FDN diferiram entre a silagem controle e as aditivadas $(\mathrm{P}<0,01)$ e sua maior concentração foi observada na silagem controle (Tabela 4). Apesar da elevação desse componente em todas as silagens, a maior concentração na silagem controle possivelmente foi ocasionada pelo consumo das frações orgânicas solúveis (Tabela 3), que, dessa forma, por efeito de concentração, elevou o teor de FDN. Nas silagens tratadas com aditivos alcalinizantes, além do menor consumo de componentes solúveis, pode ter havido também hidrólise alcalina na porção fibrosa, em virtude dos menores teores de FDN e das menores concentrações de hemicelulose nessas silagens (Tabela 4). Segundo Klopfenstein (1978), o tratamento de resíduos fibrosos com agentes alcalinizantes resulta em solubilização parcial da hemicelulose e pouca alteração da fração celulósica. Resultados similares ao deste trabalho foram encontrados por Santos et al. (2009) e Balieiro Neto et al. (2007), que, ao avaliarem agentes alcalinizantes em silagens de cana-deaçúcar também observaram menores concentrações de FDN e hemicelulose em comparação à silagem controle. 
O teor de hemicelulose na silagem tratada com $1 \%$ de cal virgem (Tabela 4) foi menor que na silagem controle $(\mathrm{P}<0,01)$, porém essa variável na silagem tratada com $1 \%$ de calcário não diferiu das demais. Esse resultado difere dos encontrados por Santos et al. (2009), pois a silagem de cana-de-açúcar tratada com $1 \%$ de cal virgem apresentou menor concentração dessa fração em relação à silagem tratada com $1 \%$ de calcário, de modo que esse autor atribuiu o fato ao maior poder hidrolítico da cal virgem.

As concentrações de FDA (Tabela 4) em todas as silagens foram mais altas que na cana-de-açúcar no momento da ensilagem (Tabela 1). Entretanto, as silagens tratadas com aditivos químicos apresentaram menor concentração $(\mathrm{P}<0,01)$ em relação à silagem controle na abertura dos silos. A elevação mais pronunciada na silagem controle pode ser atribuída às maiores perdas gasosas e menores concentrações de carboidratos solúveis (Tabela 3 ), o que contribui para o aumentou na concentração dessa fração em relação às silagens tratadas com aditivos. Siqueira et al. (2007), trabalhando com silagens de canade-açúcar tratadas com aditivos químicos, observaram que durante o período de fermentação houve elevação nos teores de FDA de 13,9 unidades percentuais para a silagem controle, enquanto as silagens tratadas com hidróxido de sódio apresentaram elevação de 5,2 unidades percentuais. Os autores sugeriram a possibilidade de o aditivo restringir a fermentação indesejável, ocasionando maior recuperação de carboidratos não-fibrosos, e possibilitando menor aumento nos teores de FDA.

A silagem controle apresentou maior $(\mathrm{P}<0,05)$ teor de celulose em comparação à silagem tratada com calcário (Tabela 4). Apesar de os valores de celulose terem diferido entre as silagens, quando se comparam seus valores no momento da ensilagem e na abertura dos silos, verificou-se aumento semelhante na concentração de 8,$3 ; 8,1$ e 7,5 unidades percentuais nas silagens controle, tratada com $1 \%$ de cal virgem e naquela tratada com $1 \%$ de calcário, respectivamente. Provavelmente, essas elevações foram ocasionadas pelas perdas de matéria seca durante o processo fermentativo, pois, apesar de Jackson (1977) comentar que agentes alcalinizantes promovem expansão das moléculas de celulose, causando ruptura das ligações intermoleculares das pontes de hidrogênio, o que poderia auxiliar em maior ataque microbiano ou maior solubilização desta fração, os dados deste trabalho confirmam relatos de Van Soest (1994) de que a fração celulose se mantém estável durante a fermentação no interior do silo.

A silagem tratada com $1 \%$ de calcário foi a que apresentou menor concentração de lignina (Tabela 4). As silagens controle e tratada com $1 \%$ de cal virgem não diferiram estatisticamente e apresentaram valor médio de $7,2 \%$. Dados similares foram relatados por Balieiro Neto et al. (2007), que avaliaram silagens de cana-de-açúcar tratadas com doses crescentes de cal virgem $(0,5 ; 1,0$ e $2,0 \%$ ) e encontraram valores de lignina variando entre 4,3 e $8,4 \%$, além do valor de $8 \%$ para a silagem tratada com $1 \%$ de cal virgem. De acordo com Klopfenstein (1980), o teor de lignina normalmente não é alterado pelo tratamento com agentes alcalinizantes, mas a ação desse aditivo leva ao aumento da taxa de digestão da celulose e hemicelulose, provavelmente em decorrência das quebras das ligações entre essas frações. $\mathrm{O}$ aumento na concentração dessa fração em comparação aos valores no momento da ensilagem pode ser justificada igualmente aos outros componentes da parede celular mencionados anteriormente, por efeito de aumento na concentração dos componentes fibrosos, em decorrência da diminuição de componentes solúveis que foram utilizados durante o período de fermentação.

\section{Conclusões}

A adição da cal virgem ou do calcário no momento da ensilagem de cana-de-açúcar melhora o padrão fermentativo das silagens em relação à silagem sem aditivo. Adicionalmente, o uso desses aditivos químicos reduz a produção de etanol, as perdas gasosas e de carboidratos solúveis da silagem da cana-de-açúcar.

\section{Agradecimentos}

À Fundação de Amparo à Pesquisa do Estado de São Paulo, pelo apoio financeiro ao projeto e pela concessão de bolsas de estudo. Aos alunos de graduação e pósgraduação do SIPOC (USP/ESALQ), pelo auxílio durante a condução do experimento.

\section{Literatura Citada}

ALLI, I.; BAKER, B.E.; GARCIA, G. Studies on the fermentation of chopped sugarcane. Animal Feed Science and Technology, v.7, n.4, p.411-417, 1982 .

ALLI, I.; FAIRBAIRN, R.; BAKER, B.E. et al. The effects of ammonia on the fermentation of chopped sugarcane. Animal Feed Science and Technology, v.9, n.4, p.291-299, 1983.

ASSOCIATION OF OFFICIAL ANALYTICAL CHEMISTS - AOAC Official methods of analysis. 15.ed. Washington, D.C.: 1990 $1298 \mathrm{p}$.

BALIEIRO NETO, G.; SIQUEIRA, G.R.; REIS, R.A. et al. Óxido de cálcio como aditivo na ensilagem de cana-de-açúcar. Revista Brasileira de Zootecnia, v.36, n.5, p.1231-1239, 2007.

BALIEIRO NETO, G.; SIQUEIRA, G.R.; NOGUEIRA, J.R. et al. Perdas na ensilagem da cana-de-açúcar cv. IAC86/2480 (Saccharum officinarum L.) com doses de óxido de cálcio. In REUNIÃO ANUAL DA SOCIEDADE BRASILEIRA DE 
ZOOTECNIA, 42., 2005, Goiânia. Anais... Goiânia: Sociedade Brasileira de Zootecnia, 2005. (CD-ROM).

BOLSEN, K.K.; TETLOW, R.M.; WILSON, R.F. The effect of calcium and sodium hydroxides and of sodium acrylate on the fermentation and digestibility in vitro of ensied whole-crop wheat and barley harvested at different stages of maturity. Animal Feed Science and Technology, v.9, n.1, p.37-47, 1983.

CASTRILlÓN, M.V.; SHIMADA, A.S.; CALDERÓN, F.M. Manipulación de la fermentación en ensilajes de caña de azúcar y su valor alimentício para borregos. Técnica Pecuária en México, v.35, p.48-55, 1978.

CAVALI, J.; PEREIRA, O.G.; SOUSA, L.O. et al. Silagem de cana-deaçúcar tratada com óxido de cálcio: composição bromatológica e perdas. In: REUNIÃO ANUAL DA SOCIEDADE BRASILEIRA DE ZOOTECNIA, 43., 2006, João Pessoa. Anais... João Pessoa: Sociedade Brasileira de Zootecnia, 2006. (CD-ROM).

CHALUPA, W.; EVANS, J.L.; STILLIONS, M.C. Influence of ethanol on rúmen fermentation and nitrogen metabolism. Journal of Animal Science, v.23, n.3, p.802-807, 1964.

DUBOIS, M.; GILLES, K.A.; HAMILTON, J.K. et al. Colorimetric method for determination of sugars and related substances. Analytical Chemistry, v.28, p.350, 1956.

FARIA, V.P. O uso da cana-de-açúcar para bovinos no Brasil. In: SIMPÓSIO SOBRE NUTRIÇÃO DE BOVINOS, 5., 1993, Piracicaba. Anais... Piracicaba: Fundação de Estudos Agrários Luiz de Queiroz, 1993. p.1-16.

FREITAS, A.W.P.; PEREIRA, J.C.; ROCHA, F.C. et al. Avaliação da qualidade nutricional da silagem de cana-de-açúcar com aditivos microbianos e enriquecida com resíduo da colheita de soja. Revista Brasileira de Zootecnia, v.35, n.1, p.38-47, 2006.

GIGER-REVERDIN, S. Characterization of feedstuffs for ruminants using some physical parameters. Animal Feed Science and Technology, v.86, p.53-69, 2000.

HOLDEN, L.A. Comparison of methods of in vitro dry matter digestibility for ten feeds. Journal of Dairy Science, v.82, n.8, p.1791-1794, 1999.

HOLMES, B.J.; MUCK, R.E. Factors affecting bunker silos densities. Madison: University of Wisconsin, 1999. 7p.

JACKSON, M.G. Review articles: The alkali treatment of straws. Animal Feed Science and Technology, v.2, n.2, p.105-130, 1977.

KLOPFENSTEIN, T.J. Chemical treatment of crops residues. Journal of Animal Science, v.46, n.2, p.841-848, 1978.

KLOPFENSTEIN, T.J. Increasing the nutritive value of crop residues by chemical treatments. In: HUBER, J.T. (Ed.) Upgrading residues and products for animals. Boca Raton: CRC Press, 1980. p.40-60.

KUNG JR., L. Preparation of silage water extracts for chemical analysis: standard operating procedure - 001 6.03.96. Worrilow: University of Delaware, Ruminant Nutrition Lab., 1996. p.309.

LAMMERS, B.P.; BUCKMASTER, D.R.; HEINRICHS, E.J. A simple method for the analysis of particle sizes of forage and total mixed rations. Journal of Dairy Science, v.79, n.5, p.922-928, 1996.

MARI, L.J.; NUSSIO, L.G. [2002]. O método Penn State Particle Size Separator para a predição do tamanho de partículas de silagens. Disponível em: <http://www.beefpoit.com.br/bn/ radarestecnicos $>$. Acesso em: 10/10/2007.

McDonald, P.; Henderson, A.R.; Heron, S.J.E. The biochemistry of silage. 2.ed. Merlow: Chalcomb Publications, 1991. 340p.
PAHLOW, G.; MUCK, R.E.; DRIEHUIS, F. et al. Microbiology of ensiling. In: BUXTON, D.R.; MUCK, R.E.; HARRISON, J.H. (Eds.) Silage science and technology. Madison: American Society of Agronomy; Crop Science Society of America; Soil Science Society of America, 2003. p.31-94.

PEDROSO, A.F.; NUSSIO, L.G.; LOURES, D.R.S. et al. Efeito do tratamento com aditivos químicos e inoculantes bacterianos nas perdas e na qualidade de silagens de cana-de-açúcar. Revista Brasileira de Zootecnia, v.36, n.3, p.558-564, 2007.

ROOKE, J.A.; HATFIELD, R.D. Biochemistry of ensiling. In: BUXTON, D.R.; MUCK, R.E.; HARRISON, J.H. (Eds.) Silage science and technology. Madison: American Society of Agronomy; Crop Science Society of America; Soil Science Society of America, 2003. p.251-304.

SANTOS, M.C. Aditivos químicos para o tratamento da canade-açúcar in natura e ensilada (Saccharum officinarum L.). 2007. 112f. Dissertação (Mestrado em Ciência Animal e Pastagens) - Escola Superior de Agricultura "Luiz de Queiroz"/ Universidade de São Paulo, Piracicaba, 2007.

SANTOS, M.C.; NUSSIO, L.G.; MOURÃO, G.B. et al. Influência da utilização de aditivos químicos no perfil da fermentação, no valor nutritivo e nas perdas de silagens de cana-de-açúcar. Revista Brasileira de Zootecnia, v.37, n.9, p.1555-1563, 2008.

SANTOS, M.C.; NUSSIO, L.G.; MOURÃO, G.B. et al. Nutritive value of sugarcane silage treated with chemical additives. Scientia Agricola, v.66, n.2, p.159-163, 2009.

SCHMIDT, P. Perdas fermentativas na ensilagem, parâmetros digestivos e desempenho de bovinos de corte alimentados com rações contendo silagens de cana-de-açúcar. 2006. 228f. Tese (Doutorado em Ciência Animal e Pastagens) - Escola Superior de Agricultura "Luiz de Queiroz"/Universidade de São Paulo, Piracicaba, 2006.

SCHMIDT, P.; MARI, L.J.; NUSSIO, L.G. et al. Aditivos químicos e biológicos na ensilagem de cana-de-açúcar. 1. Composição química das silagens, ingestão, digestibilidade e comportamento ingestivo. Revista Brasileira de Zootecnia, v.36, n.5, p.1666-1675, 2007 (supl.).

SILVA, D.J.; QUEIROZ, A.C. Análise de alimentos (métodos químicos e biológicos). Viçosa, MG: Editora UFV, 2002. 235p.

SILVA, S.A.R.; ROSA, B.; REIS, R.A. et al. Eficiência fermentativa da cana-de-açúcar ensilada com diferentes aditivos. In: REUNIÃO ANUAL DA SOCIEDADE BRASILEIRA DE ZoOTECNIA, 40., Santa Maria. Anais ... Santa Maria: Sociedade Brasileira de Zootecnia, 2003. (CD-ROM).

SIQUEIRA, G.R.; REIS, R.A.; SCHOCKEN-ITURRINO, R.P. et al. Associação entre aditivos químicos e bacterianos na ensilagem de cana-de-açúcar. Revista Brasileira de Zootecnia, v.36, n.4, p.789-798, 2007.

STATISTICAL ANALYSIS SYSTEM - SAS. User's guide: statistics. 6.ed. Cary: 1999. 956p.

Van SOEST, P.J. Nutritional ecology of the ruminant. 2.ed. New York: Cornell University Press, 1994. 476p.

VIEIRA, F.A.P.; BORGES, I.; STEHLING, C.A.V. et al. Qualidade de silagens de sorgo com aditivos. Arquivo Brasileiro de Medicina Veterinária e Zootecnia, v.56, n.6, p.764-772, 2004.

WILES, P.G.; GRAY, I.K.; KISSLING, R.C. Routine analysis of protein by Kjeldahl and Dumas methods: review and interlaboratory study using dairy products. Journal of the AOAC International, v.81, n.3, p.620-632, 1998. 